\title{
PENGEMBANGAN MODEL PERAMALAN HAMA PENGGEREK POLONG (Maruca testulatis) PADA TANAMAN KACANG HIJAU
}

\author{
Anik Kurniati $^{1 *}$, Idah Faridah ${ }^{2}$, Achmad Imroni $^{3}$, Cahyadi Irwan ${ }^{4}$, Shinta Stephani DL ${ }^{5}$, Atep \\ Budiman $^{6}$, Abdullah Wisnu ${ }^{7}$ \\ 1,2,3,4,5,6,7 Balai Besar Peramalan Organisme Pengganggu Tumbuhan \\ kurniatianik@yahoo.co.id
}

\begin{abstract}
Abstrak
Hama Penggerek Polong (Maruca testulatis) yang menyerang pertanaman kacang hijau pada fase generatif merupakan salah satu organisme pengganggu tumbuhan (OPT) yang sangat merugikan dan bisa menimbulkan ancaman kegagalan panen. Kajian Pengembangan Model Peramalan Hama Penggerek Polong pada Tanaman Kacang Hijau bertujuan untuk mendapatkan model peramalan hama penggerek polong pada kacang hijau. Penelitian dilaksanakan pada bulan Mei sampai Desember 2019 pada 20 hamparan yang tersebar di Kabupaten Cirebon di 2 kecamatan (Susukan dan Ciwaringin) masing-masing $10 \quad$ (sepuluh) hamparan. Setiap hamparan contoh diamati 30 (tiga puluh) tanaman contoh yang terbagi dalam 3 petak alami contoh masing-masing 10 tanaman contoh yang ditentukan secara acak sistematis. Pengamatan dilakukan secara visual dengan menghitung jumlah polong dan jumlah polong bergejala pada masing-masing tanaman contoh. Untuk mendapatkan model peramalan serangan penggerek polong, dilakukan analisis dengan metode analisis regresi linear. Hasil penelitian menunjukkan intensitas serangan penggerek polong pada masa panen kedua (9 MST) secara nyata dipengaruhi dengan intensitas serangannya pada awal pembentukan polong (7 MST) dan model peramalan serangannya adalah sebagai berikut: $Y=10,98 X+2,36 \quad\left(r^{2}=0,65\right.$; Sig $F=$ 5,79E-06), dimana $\mathrm{Y}=$ Intensitas serangan Penggerek Polong pada umur 9 MST; $\mathrm{X}=$ Intensitas serangan Penggerek Polong pada umur 7 MST. Model peramalan intensitas serangan hama penggerek polong dan jumlah larva adalah sebagai berikut: $\mathrm{Y}=2.4146 \mathrm{x}+2.7987 ; \mathrm{R}^{2}=$ 0,7639; $N=13 ; \quad$ Sig $=9.38 E-05 ; \operatorname{dimana}(X)$
\end{abstract}

adalah jumlah populasi larva pada minggu ke 7 dan (Y) adalah intensitas serangan hama pengerek polong pada umur $9 \mathrm{MST}$.

Kata kunci: kacang hijau, model peramalan, $M$. testulatis

\section{Abstract}

Pod borer (Maruca testulatis) which attacks the planting of mung beans in the generative phase is one of the plant pests (OPT) which is very detrimental and can pose a threat of crop failure. The Study on Development of Peach Borer Forecasting Forecast Model for Green Bean Plants aims to obtain a model of forecasting pod borer on green beans carried out in May to December 2019 on 20 stretches spread in Cirebon Regency which are spread in 2 sub-districts (Susukan and Ciwaringin) respectively 10 (ten) overlays. In each sample field, 30 (thirty) sample plants were divided into 3 natural plots of 10 sample plants each, which were determined systematically at random. Observations were made visually by counting the number of pods and the number of symptomatic pods in each sample plant. To get the pod borer attack forecasting model, an analysis using linear regression analysis method was performed. The intensity of pod borer attack during the second harvest (9 MST) was significantly affected by the intensity of the attack at the beginning of pod formation (7 MST) and the attack forecasting model was as follows: $Y=10.98$ $X+2.36\left(r^{2}=0.65 ;\right.$ Sig $\left.F=5.79 E-06\right)$, where $Y=$ Intensity of Pod Borer attack at the age of $9 \mathrm{MST}$; $X=$ Intensity of Pod Borer attack at the age of 7 MST. The model of forecasting the intensity of pod borer attack and the number of larvae is as follows: $Y=2.4146 x+2.7987 ; R 2=0.7639 ; N=$ 13; Sig $=9.38 E-05$; where $(X)$ is the number of 
larvae populations at week 7 and $(Y)$ is the intensity of pod attack pests at the age of $9 \mathrm{MST}$.

Keywords: mung beans, forecasting model, $M$. testulatis

\section{Pendahuluan}

Kacang hijau (Mung Bean) adalah sejenis tanaman budidaya dan palawija yang dikenal luas di daerah tropika. Tumbuhan yang termasuk suku polong-polongan (Fabaceae) ini memiliki banyak manfaat dalam kehidupan sehari-hari sebagai sumber bahan pangan berprotein nabati tinggi. Kacang hijau di Indonesia menempati urutan ketiga terpenting sebagai tanaman pangan legum, setelah kacang hijau dan kacang hijau.

Tanaman kacang hijau memiliki prospek yang baik untuk dikembangkam di Indonesia, terutama di lahan sawah pada musim kemarau. Di samping itu potensi pasar terhadap kacang hijau terlihat cukup besardan terus bertambah. Hal tersebut karena kacang hijau merupakan salah satu tanaman pangan penghasil protein nabati yang penting. Kandungan proteinnya dapat mencapai 20 - $24 \%$, oleh karena itudapat dijadikan sebagai sumber protein dan vitamin dalam pemenuhan kebutuhan sehari - hari.

Kebutuhan akan kacang hijau terus meningkat setiap tahunnya seiring dengan berkembangnya industri pengolahan bahan baku kacang hijau dan kesadaran masyarakat akan pentingnya mengkonsumsi makanan sehat.Oleh karenanya, peningkatan produksi kacang hijau merupakan suatu keharusan. Namun, upaya-upaya peningkatan tersebut menghadapi berbagai kendala. Salah satu kendala yang banyak ditemui di lapangan adalah serangan organisme pengganggu tumbuhan (OPT). Serangan OPT merupakan faktor pembatas produksi kacang hijau. Hama yang banyak menyerang tanaman kacang hijau, terutama pada masa generatif adalah Penggerek Polong yang disebabkan oleh hama Maruca testulatis

Pada awal fase berbunga, serangga dewasa mulai meletakkan telurnya di kuncup bunga dan bunga, namun telur juga dapat ditemukan pada daun, pucuk tanaman, danpolong. Telur berbentuk oval, berwarna putih, dan menetas dalam tiga hari (Singhet al. 1990). Larva muda yang baru menetas langsung menyerang atau memakan kuncup bunga, bunga, dan polong. Singhet al. (1990) menyatakan bahwa kehilangan hasil kacang tunggak akibat serangan penggerek polong berkisar antara 2080\%. Di Banjarnegara, Jawa Tengah, kehilangan hasil kacang hijau akibat serangan penggerek polong berkisar antara 13-59\% (Indiati 2007).

Serangga ini tersebar ke seluruh daerah tropis. Di Jawa dan Sumatera tanaman inangnya adalah tanaman kacang - kacangan. Larva dapat menimbulkan kerusakan pada batang. Batang yang masih lunak di dekat pucuk tanaman lebih disukai. Kerusakan yang disebabkan oleh larva instar akhir sering menyebabkan kematian pada bagian tanaman di atas liang gerekan. Larva dapat menyebabkan kerusakan pada daun dengan melipat daun - daun trifoliat yang masih muda dan memakan bagian - bagian daun dari dalam lipatan tersebut. Bila serangan berat, bunga dan polong muda terbentuk akan hilang. Larva menggerek kulit polong, kemudian masuk dan menggerek biji meninggalkan lubang bekas gerekan pada polong.

Sehubungan dengan hal tersebut, maka pada Tahun Anggaran 2019, Balai Besar Peramalan Organisme Pengganggu Tumbuhan Jatisari mewujudkan kegiatan pengembangan model peramalan hama penggerek polong (Maruca testulatis) pada kacang hijau yang mempunyai tujuan untuk mendapatkan model peramalan hama penggerek polong (Maruca testulatis).

\section{Bahan dan Metode}

\section{Tempat dan Waktu}

Kegiatan pengembangan model peramalan hama penggerek polong (Maruca testulatis) pada kacang hijau dilaksanakan mulai dari bulan Mei sampai dengan Desember 2019 di Kabupaten Cirebon.

\section{Bahan dan Metode}

Alat yang digunakan dalam kegiatan ini adalah papan pengamatan, pH meter, ATK, Kayu, Papan triplek, Mikroskop, buku identifikasi serangga, botol pial, cutter, GPS dan komputer.

Bahan yang digunakan dalam kegiatan ini adalah blangko pengamatan, ATK, papan pengamatan, Alkohol 70\%, Tisue dan kertas HVS ukuran A4.

Kegiatan dilaksanakan di 20 hamparan yang tersebar di Kabupaten Cirebon. Pada setiap hamparan terpilih diambil 3 petak alami contoh. Dan petak alami diamati 30 tanaman secara acak sistematik. Metode pengambilan sampel contoh yang digunakan adalah metode diagonal. Jarak antara tanaman satu dengan yang lain adalah 5 rumpun. jumlah tanaman yang diamati adalah 1800 tanaman (20 hamparan x 90 tanaman).Pengamatan dilakukan selama satu periode tanaman, yaitu dari mulai tanam sampai dengan menjelang panen.

Parameter yang diamati adalah intensitas serangan dan populasi hama utama tanaman kacang hijau pada generatif. Penghitungan populasi penggerek polong dilakukan secara visual. Untuk menilai kerusakan polong terserang, digunakan rumus kerusakan mutlak (Ditlin TP, 2008). Rumus intensitas serangan mutlak adalah sebagai berikut: 


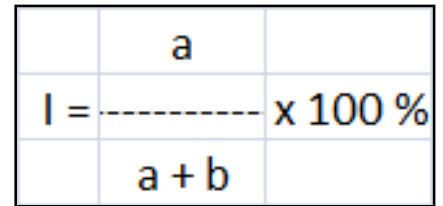

Keterangan :

I : Intensitas serangan (\%)

a : Banyaknya polong yang rusak mutlak

b : Banyaknya polong yang tidak rusak

Faktor pendukung lainnya yang perlu dikumpulkan adalah data varietas, $\mathrm{pH}$ tanah dan dosis pemupukan di masing-masing lokasi kegiatan. Serta dilakukan pengamatan terhadap populasi larva dari hama penggerek tersebut dengan mengamati 10 polong yang terserang dan 10 polong yang tidak terserang pada setiap hamparannya. Pengamatan polong dimulai ketika polong mulai terbentuk.

Data hasil pengamatan dianalisa dengan menggunakan analisis regresi linear sederhana pada tingkat kepercayaan 95\%. Analisis regresi linear sederhana untuk memperoleh hubungan antara intensitas serangan di pembungaan dengan intensitas di akhir serta populasi larva pada polong. Persamaan regresi linear sederhana adalah sebagai berikut :

$\mathrm{Y}=\mathrm{a}+\mathrm{bx} 1$

$\mathrm{Y}=$ Intensitas serangan di menjelang panen

$\mathrm{a}=$ intersep

$\mathrm{x} 1=$ intensitas serangan di awal

\section{Hasil dan Pembahasan}

\section{Perkembangan Intensitas Serangan Hama Penggerek Polong pada Kacang Hijau}

Hama penggerek polong pada kacang hijau Maruca Testulalis merupakan salah satu hama utama tanaman kacang hijau di Kabupaten Cirebon. Hama ini mulai menyerang ketika pertanaman kacang hijau berumur 7 MST yaitu ketika tanaman kacang hijau sudah membentuk polong
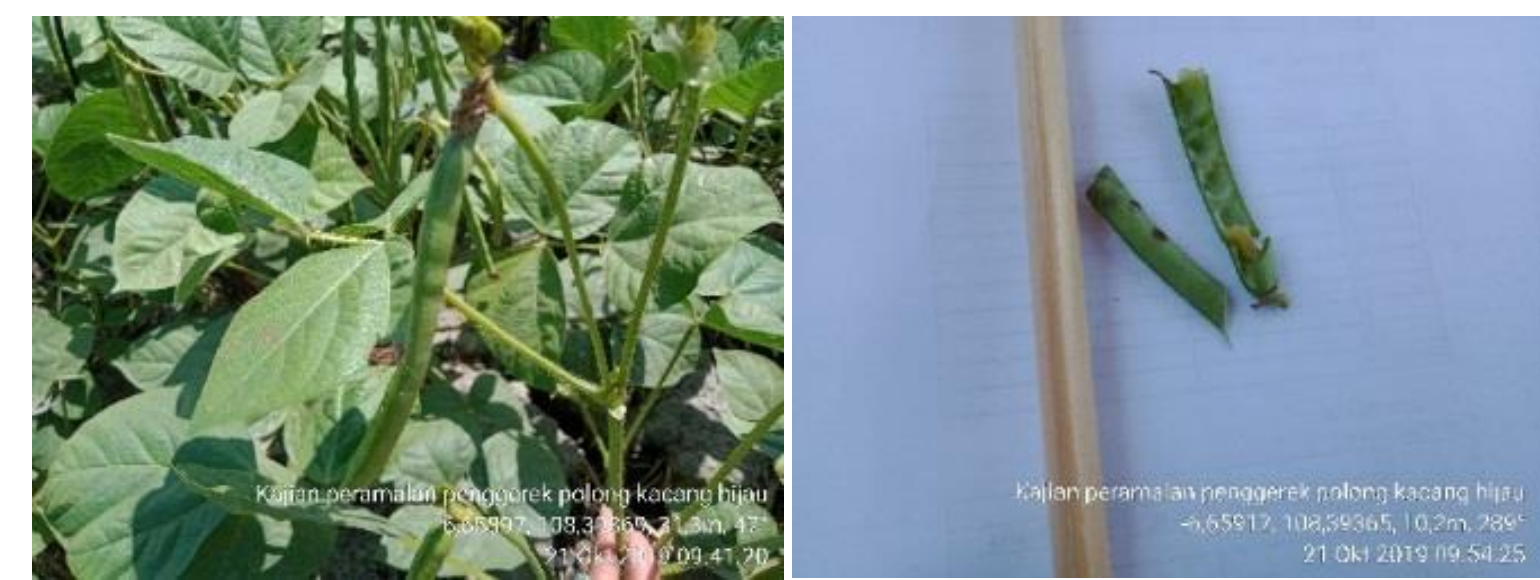

Gambar 1. Gejala Serangan Hama Penggerek Polong Kacang Hijau.

Gejala kerusakan yang ditimbulkan oleh hama tersebut adalah adanya lubang pada polong kacang hijau dan apabila dibuka akan ditemukan larva penggerek polong. Gejala pada biji akan terjadi kerusakan akibat bekas gerekan dari hama tersebut. Selain itu juga akan dijumpai bekas kotoran dari hama penggerek polong ini pada polong kacang hijau. 


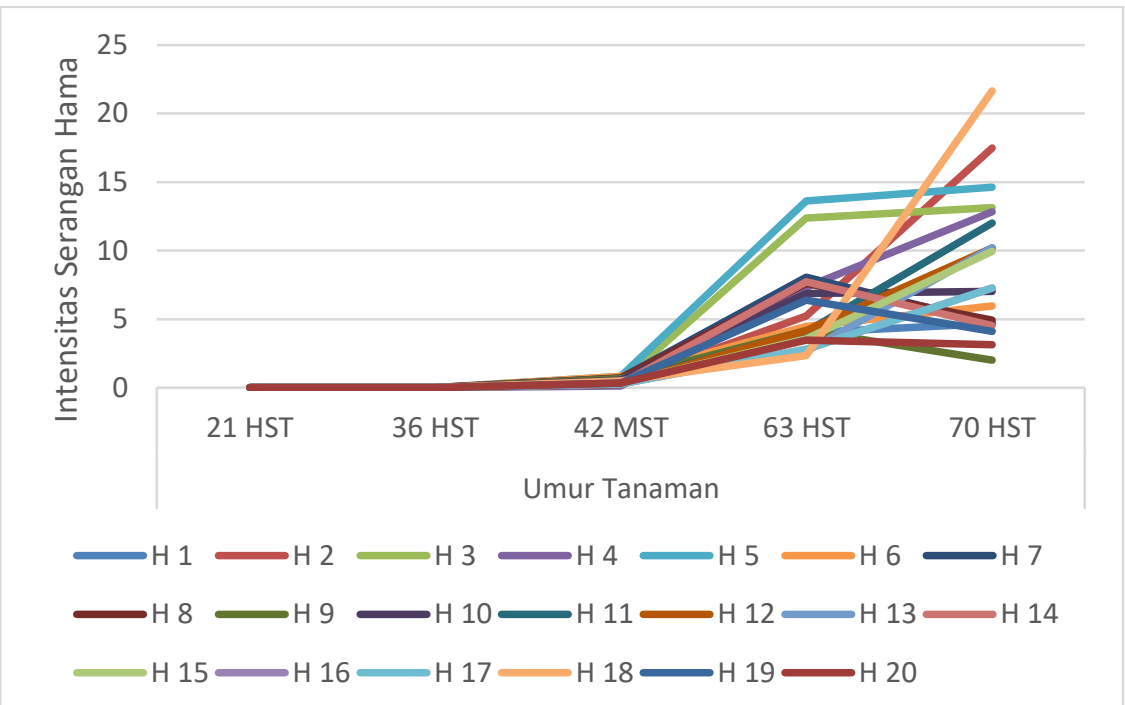

Gambar 2. Perkembangan Intensitas Serangan Hama Penggerek Polong Kacang Hijau.

Dari grafik (Gambar 2) dapat dilihat bahwa serangan hama dimulai pada umur 42 HST yaitu ketika terbentuknya polong muda. Menurut Faizin et al (2019), serangan penggerek polong kacang hijau dimulai pada fase pembungaan dengan gejala yaitu bunga saling berdempetan. Pada kegiatan ini, kelompok telur hama dan gejala awal pada fase pembungaan tidak dapat dijumpai. Hal ini dikarenakan karena tingginya aplikasi pestisida di lapangan. Dari hasil survei, bahwa petani menggunakan pestisida untuk pengendalian hama penggerek polong setiap minggu sekali.

Gambar 2 juga menunjukkan bahwa intensitas serangan hama penggerek polong kacang hijau pada umur 70 HST cenderung mengalami peningkatan, hal ini desebabkan karena tidak ada aplikasi pestisida setelah kacang hijau panen untuk pertama kali (umur 60-65 HST).

\section{Pemodelan Peramalan Hama Penggerek Polong Kacang Hijau}

Model peramalan hama penggerek polong kacang hijau disusun berdasarkan intensitas serangan hama di awal pertanaman dan intesitas serangan hama menjelang panen.

Model peramalan yang disusun dari hasil intesitas intensitas serangan hama pada minggu ke $\mathrm{x}$ dengan intesitas serangan hama menjelang panen adalah $\mathrm{Y}=10.981 \mathrm{x}+2.3638 \mathrm{R}^{2}=0.6506 ; \mathrm{N}=22 ; \mathrm{Sig}$ $=5.79 \mathrm{E}-06$, dimana $(\mathrm{X})$ intensitas serangan hama penggerek polong pada umur 7 MST (X) dan (Y) intensitas serangan hama penggerek polong pada umur $9 \operatorname{MST}(\mathrm{Y})$.

Hasil analisis regresi linear sederhana antara intensitas serangan hama penggerek polong di umur 7 MST dengan intensitas serangan hama penggerek polong di umur $9 \mathrm{MST}$, R Square $\left(\mathrm{R}^{2}\right)$ yang diperoleh sebesar $65,06 \%$. Hal ini dapat dikatakan bahwa presentase serangan hama penggerek polong di umur 7 MST memiliki hubungan yang kuat terhadap intensitas serangan hama penggerek polong di umur 9 MST. Hasil persamaan tersebut menunjukkan bahwa intensitas serangan hama pada umur 7 MST mempunyai kontribusi sebesar $65,06 \%$ dalam meningkatkan intensitas serangan hama pada umur 9 MST.

Hasil uji $F$ menunjukkan bahwa nilai Signifikasi F nya sebesar 5,79E-06. Hal ini menunjukkan bahwa nilai Signifikasi F nya lebih kecil dari 0,05 , dan ini berarti bahwa hubungan keduanya mempunyai pengaruh yang nyata .

Model peramalan yang kedua disusun dari hasil pengamatan larva hama penggerek polong pada minggu ke 7 dengan intensitas serangan hama pengerek polong pada saat menjelang panen. Persamaan model yang didapat adalah $\mathrm{Y}=2.4146 \mathrm{x}+2.7987 ; \mathrm{R}^{2}=0,7639$; $\mathrm{N}=13$; Sig $=9.38 \mathrm{E}-05$; dimana $(\mathrm{X})$ adalah jumlah populasi larva pada minggu ke 7 dan (Y) adalah intensitas serangan hama pengerek polong pada umur 9 MST.

Hasil analisis regresi linear sederhana antara jumlah populasi larva pada umur 7 MST dengan intensitas serangan hama pengerek polong pada umur 9 MST, R Square $\left(\mathrm{R}^{2}\right)$ yang diperoleh sebesar $76,39 \%$. Hal ini dapat dikatakan bahwa jumlah larva pada di umur 7 MST memiliki hubungan yang kuat terhadap intensitas intensitas serangan hama pengerek polong pada umur 9 MST. Hasil persamaan tersebut menunjukkan bahwa kepadatan populasi hama pada umur 7 MST mempunyai kontribusi sebesar 76,39\%dalam meningkatkan intensitas serangan hama pengerek polong pada umur 9 MST.

Hasil uji $F$ menunjukkan bahwa nilai Signifikasi F nya sebesar 9.38E-05. Hal ini menunjukkan bahwa nilai Signifikasi F nya lebih kecil dari 0,05 , dan ini berarti bahwa hubungan keduanya mempunyai pengaruh yang nyata. Model peramalan yang didapat masih memerlukan evaluasi di berbagai 
daerah sehingga dapat menghasilkan model yang dapat diaplikasikan di luar daerah tempat kegiatan berlangsung.

\section{Kesimpulan}

Dari hasil dan pembahasan dapat diambil kesimpulan model peramalan penyakit hama penggerek polong kacang hijau yang didapat adalah

1. $\mathrm{Y}=10.981 \mathrm{x}+2.3638 \mathrm{R}^{2}=0.6506 ; \mathrm{N}=22 ; \mathrm{Sig}=$ 5.79E-06 dimana $(\mathrm{X})$ intensitas serangan hama penggerek polong pada umur 7 MST dan (Y) intensitas serangan hama penggerek polong pada umur 9 MST

2. $\mathrm{Y}=2.4146 \mathrm{x}+2.7987 ; \mathrm{R}^{2}=0,7639 ; \mathrm{N}=13 ; \quad \mathrm{Sig}=$ 9.38E-05; dimana $(\mathrm{X})$ adalah jumlah populasi larva pada minggu ke 7 dan (Y) adalah intensitas serangan hama pengerek polong pada umur 9 MST.

\section{Daftar Pustaka}

Anonim. 1981. Kacang Hijau - edisi kedua. Balittan: Malang Penelitian Pertanian 8(2). Balai Penelitian Tanaman Pangan. Bogor

Direktorat Jenderal Tanaman Pangan Direktorat Perlindungan Tanaman Pangan. 2008. Pedoman Pengenalan dan Pengendalian Organisme Pengganggu Tumbuhan pada Tanaman Kacang Kacangan dan Umbi - Umbian Edisi Kacang Hijau.

Direktorat Perlindungan Tanaman Pangan. Direktorat Jenderal Tanaman Pangan. Kementrian Pertanian. 2011. Pedoman Rekomendasi Pengendalian Organisme Pengganggu Tumbuhan (OPT) Tanaman Serealia.

Direktorat Perlindungan Tanaman Pangan. Direktorat Jenderal Tanaman Pangan. Kementrian Pertanian. 2012. Pedoman Pengamatan dan Pelaporan Perlindungan Tanaman Pangan.

Indiati, S.W. 2007. Pengendalian Hama Penggerek Polong pada Pertanaman Kacang Hijau. Jurnal penelitian dan Informasi Pertanian Agrin 11(2): 2007.

Indiati, S.W. 2010. Efektifitas Pengendalian Biologi dan Kimiawi Hama Penggerek Polong Kacang Hijau. Jurnal Penelitian Tanaman Pangan. 29(1): 2010.

Setyaningrum, C.A., S.Y.J. Prasetyo. 2018. Sistem Peramalan Serangan Organisme Pengganggu Tanaman Menggunakan Metode Double Exponential Smoothing Berbasis Google Map. Indonesian Journal of Modelling and Computing 1 1-9: 2018.

Zulaikha, B.P. Soekarno, A. Nurmansyah. 2018. Pemodelan Keparahan Penyakit Blas pada
Tanaman Padi di Kabupaten Subang. Jurnal Fitopatologi Indonesia 14(2): 2018. 